\title{
Medium Sized High Tech International Acquisitions: A Longitudinal Perspective (1990-2011)
}

\author{
Olivier Meier \\ Senior Professor and Qualified Research Supervisor, University of Paris Est-Créteil - IRG \\ 52 avenue de la Motte Picquet, Bâtiment B, 75015 Paris, France \\ Tel: 33-1-6413-4481_E-mail: omeier@yahoo.fr \\ Jean-Yves Saulquin \\ Finance Professor, Loire ValleyUniversity/CRESCEM/ESCEM \\ ESCEM 1 rue Léo Delibes BP 0535 Tours Cedex 3, France \\ Tel: 33-2-4771-7110 E-mail: jysaulquin@escem.fr \\ Guillaume Schier (Corresponding author) \\ Finance Professor, Loire Valley University/CRESCEM/ESCEM \\ ESCEM 1 rue Léo Delibes BP 0535 Tours Cedex 3, France \\ Tel: 33-2-4771-7290 E-mail: gschier@escem.fr
}

Received: September 9, 2011

Accepted: April 16, $2012 \quad$ Published: June 1, 2012

doi:10.5539/ibr.v5n6p94

URL: http://dx.doi.org/10.5539/ibr.v5n6p94

\begin{abstract}
This article examines the various forms and strategical options that are found and employed when merging companies of any size with medium-sized technological companies, with a view to understanding what outcomes are involved. This research paper is based on a sample consisting of 5738 mergers and acquisitions transactions in the high-tech sector, particularly those involving innovative companies with technological interests. The aim of this research is to show how these strategic manoeuvres operate, using a multi-criteria analysis chart that includes the size of the company, the level of participation, the nature of diversification, the duration of transactions and value ratios. In this way, the research will help to provide better understanding of the characteristics of these technological merger acquisition operations, creating a typology of operations and manoeuvres and correcting some of the beliefs commonly held.
\end{abstract}

Keywords: High-tech, Acquisition strategies, Internationalisation, Diversification

\section{Introduction}

Research into merger acquisitions is regularly investigated by researchers and practitioners, particularly with regard to the challenges, the underlying strategic motivation and the integration policies followed. There are a great many works that examine the lines of development (diversification, vertical integration, specialisation) and strategic process management (decision-making, negotiation, integration within the new body). Nonetheless, although the motivation for mergers of this nature may have been dealt with in academic literature, there are still many questions to be answered concerning the methods and practical conditions involved in this regrouping. This is particularly the case when the features of these newly grouped companies include mismatches of size and information combining to create innovation.

With this in mind, our article examines the various forms and mechanisms of technological mergers between companies of any size and medium-sized targets, in order to understand the practices, methods and outcomes at stake. In our paper, we hope to show how these strategic mergers operate, using a multi-criteria analysis chart that includes the size of the company, the level of participation, the nature of diversification, the duration of transactions and value ratios. 
After briefly recapping the topic of our research and the questions it raises (1), we shall present our sample group (2) followed by the main findings from its descriptive analysis (3). We shall then provide a more searching investigation into the methods of "takeover" that are revealed by 5 acquisitions modes. We shall examine whether they are influenced by the size and nature of diversification and look into the link between certain fundamental characteristics of the transactions and the type of diversification sought (4). Our work shows the diversity and complexity of transactions in this beacon sector of the economy. Our approach, based on multiple criteria, helps us to highlight certain specific features that are peculiar to the international diversification of companies, particularly small companies.

\section{The Challenges of Strategic Mergers in the High-tech Sector}

We hardly need to remind ourselves that research and development is a key factor of success, but there are other reasons encouraging businesses to seek partners with whom and thanks to whom they may acquire new intangible assets (know-how, skills). These include costs relating to R\&D, the uncertainties linked to technological change and the difficulties in maintaining the expertise in numerous technological fields (Granstrand \& Sjolander, 1990). Small and medium-sized enterprises (SMEs) can benefit from an alliance with large companies in a system of complementary strategic nature. This is why a great many works have examined the development of innovative companies in the context of technological mergers with major corporations (Luypaert \& Huyghebaert, 2007; De Man \& Duysters, 2005; OCDE, 2000). These research works look into the specific nature of strategically interdependent relationships within the framework of mergers, relationships characterised by an appreciation of the organisational differences and by good management of the variety of information. The focus of the researchers is directed particularly at the ability of the firms to transfer resources and competencies between each other. The same applies to the potential in terms of technological integration and innovation (Aslani \& Negassi, 2006) and on growth outlooks (Lee et al., 2001). However, these kinds of merger do not happen of their own accord and require specific organisational and operational methods for the duration of the process. Indeed, this process of combining businesses presents methods and constraints that must be observed meticulously in order to define them as accurately as possible. Let us think about the difficulties relating to the importance of sharing information. The situation is all the more sensitive when the knowledge circulated is tacit (Coff, 1999; Cohen \& Levinthal, 1990) and the role of the human asset in the process of value creation is made more important (Holms \& Schmitz, 1990). Various research papers highlight these very organisational and structural risks associated with this type of merger, taking into account the challenges as well as the mismatch of size and information existing between the companies in question (Puranam et al, 2000; Paruchuri et al., 2006).

Cassiman and Veugelers (2202) put forward the fact that resorting to external growth is part of an approach favouring the acquisition of knowledge, legitimising acquisition in the high-tech field. This phenomenon may be compared with the way a closed innovation system moves to an open innovation system (Chesbrough, 2003). Reference may also be made to the works of Williamson (1975), who proposes an efficient innovation process based on the purchase of small innovative companies by large firms.

Vermeulen and Barkema (2001) suggest that the acquisition of companies is an effective way of making a technological revival and/or ensuring technological diversification whilst at the same time avoiding the traps associated with the renewed use of the fundamental knowledge held by the company initiating the process. In this approach, Capron and Mitchell (1998) have showed that when the acquisition involves a high degree of transfer of knowledge between the target company and the initiator, this creates rapid development of the R\&D competencies of the re-formed organisation in addition to accelerating the market launch of new products.

Although many authors (Salant, 1984; Katz \& Shapiro, 1986; Inkpen, 2000) highlight the importance of external growth in the field of high-technology, it has to be admitted that to our knowledge there are very few studies helping to quantify this phenomenon. Inkpen's findings (2000) help us to understand this phenomenon in the context of a specific sector (information technology and communication) in which these transactions appear to represent about one fifth of all operations. Furthermore, Granstrand and Sjölander (1990) appear to suggest that these operations mainly involve major companies purchasing smaller target companies. This article therefore aims to fill in a gap in existing literature by looking at medium-sized acquisitions in the high-technology sector.

\section{Data Collection Procedure and Sample}

The data is taken from the SDC Platinum (Thomson Reuters) database that compiles records of acquisition transactions around the world. We have selected share acquisition transactions from the last 20 years (1990-2011) of medium-sized high-tech companies worth between 10 and 500 million euros (market values of total equity recalculated on the base of transaction values). 
Transactions were used where the target and the acquirer belonged to a high-tech sector (according to the SDC Platinum database list), giving an initial sample of 16,538 transactions. We then eliminated stock repurchase or capital reduction transactions, bringing the total number of transactions to 7788 acquisitions.

Finally, we eliminated any transactions for which we did not have criteria relating to the size of the acquirer as well as transactions carried out by companies under any specific form of bankruptcy or receivership proceedings. The final sample was thus brought down to 5738 acquisitions.

For each transaction, the following data were collected: the announcement date, the date the transaction was completed, the percentage of shares held before the transaction, the percentage held after the transaction in addition to the total value of the transaction in millions of dollars and the relative acquisition premium (calculated using the average market price of the target over the 4 weeks preceding the transaction). For each target and each acquirer, we identified the name of the company, the sector code (SDC codification for the high-technology sectors), the country of origin and the name of the sector (SIC classification). Finally we identified data that were specific to the target (annual turnover and operating income (EBIT) in millions of dollars for the year preceding the transaction) and to the acquirer (value of total equity in millions of dollars).

\section{General Characteristics of Medium-sized High-tech Acquisitions}

Table 1 shows the breakdown of our sample of 5 758medium-sized high-tech acquisition transactions carried out worldwide over the last 20 years. What are the main findings from the statistical processing of our data?

First of all, it may be observed that on average $30 \%$ of these High-Tech acquisition transactions also include international diversification. Here, international diversification is measured by comparing the country of origin of the target and the acquirer (code 1 if the countries of origin are different, code 0 if they are the same). This result is in keeping with recent merger-acquisition trends around the world, in which over the last 10 years, cross-border acquisitions have accounted for nearly $36 \%$ of transactions (Meier \& Schier, 2012). In particular, we find that these acquisition transactions correspond to a form of sectoral diversification (73\%), measured by comparing high-tech sector codes held in the SDC Platinum database (code 1 if the sectoral coding is identical). These results contrast with those obtained from more general data indicating a percentage drop in the number of acquisition transactions incorporating sectoral diversification (Lichtenberg, 1992; Montgomery, 1994).

\section{Insert Table 1 Here}

Over the period, the average transaction amount is of 86.62 million dollars. There is no significant size difference between the general case and the case in which the acquisition is linked with international diversification (average transaction of 80 million dollars) or sectoral diversification (average transaction of 87 million dollars).

Figure 1 below illustrates development of these transactions in waves, over the period studied. Where the cyclical nature of the development in waves is known of major listed companies (Gugler, 2003; Rhodes-Kropf \& Viswanathan, 2004), it is interesting to note that this characteristic is also found here in relation to medium-sized companies. As we are dealing with high-technology companies, it may be observed that the tip of the wave relates to the period 1998-2001, the peak of the internet bubble. We therefore have here concurrence between the wave observed on the market in general and the trends seen in medium-sized acquisitions in high-technology sectors.

\section{Insert Figure 1 Here}

Table 2 presents the geographic distribution of these transactions by identifying the acquirer's country of origin. We must highlight the strong domination of the United States in this field, that far exceeds the GDP ratios between the countries. Analysis of the country of origin of the targets (not listed) shows the high correlation between the principle acquirer countries and the principle target countries. The internationalisation associated with these operations is thus very tightly linked to intra-zone transactions and mainly, to intra-OECD transactions.

Insert Table 2 Here

Finally, table 3 presents the principle sectors of origin of the initiating companies. The first 8 acquirer sectors represent almost $90 \%$ of the operations (Business Services; Pre-packaged Software; Telecommunications; Electronics and Electronic Equipment; Drugs and Pharmaceuticals; Measuring, Medical and Photographic Equipment and Clocks; Computer and Office Equipment; Communications Equipment).

Insert Table 3 Here

\section{Main Results}

In addition to the general findings with regard to the operation outcomes and the initiators, we hope to decipher the main acquisition methods in the high-technology sector. To this end, we shall examine the various takeover strategies implemented as well as the types of diversification involved. 


\subsection{Takeover Strategical Options}

There are several possible takeover strategies. Our results would suggest 5 possible strategical options (figure 2) characterised by the percentage of control before and after the transaction. From our sample we shall then distinguish 5 takeover options: option 1 with direct takeover (one phase) that consists in taking immediate control of the target from zero \%; option 2 consisting of a takeover in two phases (takeover of the target after an initial acquisition of holdings); option 3 consisting in an initial acquisition of holdings ; option 4 is a consolidation of the holdings' acquisition without a majority takeover and option 5, unlike 4, consists in consolidating control, possibly to the extent of a $100 \%$ takeover of the target.

\section{Insert Figure 2 Here}

One of the major characteristics of the high-technology sector appears to be the dominant nature of option 1 that represents over $75 \%$ of the situations. The move through an intermediate situation of holdings' acquisition only represents $8 \%$ of cases (option 2). Options 3, 4 and 5 represent $6 \%, 5 \%$ and $7 \%$ of situations respectively. The most commonly represented case is the movement from $0 \%$ to $100 \%$ of the target, representing over two-thirds of acquisition transactions of our total sample.

Insert Figure 3 Here

We now propose to make a further breakdown of these takeover methods according to the size of the transactions and the nature of the associated diversification. The size of the transactions is studied here by crossing the size of the target with the size of the acquirer. Figure 4 gives us the breakdown of transactions per size. The target companies have been divided into quartiles, taking as criterion the size of the market value of total equity estimated using transaction values. Thus, $25 \%$ of transactions relate to target companies whose value is between 10 million and 26.72 million dollars inclusive. The second quartile involves target companies valued between 26.72 million and 63.9 million dollars inclusive. The third quartile includes transactions up to 162.25 million dollars. The initiating companies (acquirers) have been regrouped taking the same thresholds in order to obtain comparable groups of corporate transactions. Figure 4 below shows all the results. Following this, we have defined two size groups per acquirer and per target, i.e. four configurations of typified acquisitions.

Insert Figure 4 Here

Table 4 presents the results obtained. We note that for small transactions (group 1 of acquirers and group 1 of targets), option 1 is followed practically exclusively (9 cases out of 10). We observe that, in the case of a strategy involving international diversification, this strategy is followed even more so, representing almost $96 \%$ of cases. Contrary to this, for very large scale transactions (group 2 of acquirers and group 2 of targets), option 1 only represents $63.6 \%$ of cases. Moreover, for this group of transactions, the use of option 1 falls to $55 \%$ for cases involving international diversification. These two observations are arguments for differentiated risk management when it comes to international acquisitions. In our sample, the small structures appear to favour management through rigid managerial control involving a total takeover, whereas the larger companies seem to opt for risk management that is more along the lines of financial management.

\section{Insert Table 4 Here}

We can also notice that, when small structures (acquirer group 1) are interested in larger targets with a desire for international diversification (target group 2), their behaviour tends to resemble that of the larger entities (acquirer group 2), with only $60 \%$ opting for option 1 and wider diversity of the other strategies. Where international diversification appears to play a major role in the methods of risk management for High-Tech acquisitions, sectoral diversification seems to promote "standardisation" of behaviour by reducing the spread of strategies implemented in accordance with size. The paragraph below aims to examine more deeply the impact of the diversification sought (international or sectoral) on the risk management methods of these operations.

\subsection{The Impact of the Diversification Types on the Characteristics of the Operations}

To characterise the operations, we have used the four following assessment criteria: The duration of the acquisition process estimated in number of days between the announcement date and the completion date, the average acquisition premium noted (calculated using the average market price over the 4 weeks preceding the announcement), the ratio, Total Equity Value / Turnover of the target and the ratio, Total Equity Value / Operating Income (EBIT value) of the target.

For each of these criteria, we distinguish the average observed per size group (acquirer/target) and per type of diversification (no diversification, international, sectoral or double diversification). For each average calculated, we specify in italics the number of operations concerned. Finally, for each criterion, the average of the total sample per 
size group is given. We compute two t-test statistics. T-test1 is testing mean differences for each size group for a given type of diversification. T-test 2 is testing mean differences for each type of diversification for a given size group. Statistical significance levels at $5 \%$ and $1 \%$ are denoted by $(*)$ and $(* *)$ respectively. Table 5 a and $5 \mathrm{~b}$ show the results obtained.

Insert Table 5a Here

The average length of time between the announcement and completion dates is 69.6 days. We can see that this period is shorter in all cases when a large-sized acquirer takes over a small-sized target. Conversely, the period is greatly extended when a small-sized acquirer takes over a large-sized target. International diversification tends to shorten the length of the implementation period, whereas sectoral diversification appears to have no significant effect on this criterion. Here we find another difference between sectoral and international diversification. The shortened time periods may be interpreted in different ways: better upstream preparation of the transaction and/or greater desire to push the takeover through. The average acquisition premium observed is $51.5 \%$. The average control premium worldwide for the period 1999-2011 is around 20\% (Meier \& Schier, 2012). There is a very great difference observed, reflecting both the size of the transactions and the level of risk associated with the high-technology sector. Moreover, the results obtained show that the combination of technological risk, international risk and risk related to the size of the operators leads to the observation that, in this kind of configuration, there is an average control premium of over $90 \%$. Sectoral diversification is linked to a lower level of risk for small transactions and an average risk level for other transactions. The absence of diversification clearly plays a role of technological risk limitation, except in the case of the smallest transactions.

Insert Table $5 \mathrm{~b}$ Here

Table $5 \mathrm{~b}$ present the results of ratios comparing the total equity market value of the targets with their turnover or operating income (EBIT). The average ratio between total equity value and turnover is 22.6, compared with a worldwide average of 1.23 for the period 1999-2011 (Meier \& Schier, 2012). Naturally, this reflects the reality of the high-tech sector in which target companies may be re-purchased purely for their technological potential. It should be noted that some results are difficult to interpret because of the extreme sensitivity of this ratio in this particular context (a very low turnover has the effect of mechanically increasing the ratio dramatically). Nevertheless, table $5 \mathrm{~b}$ highlight the enhanced value of international acquisition transactions, except where small transactions are concerned. The observations may also be interpreted in terms of risk, with the large groups taking more risks on acquisitions with great technological potential, whereas the small structures limit their risk with acquisitions that have a lower value ratio.

\section{Conclusion}

This article shows the diversity of objectives sought, of takeover procedures and of management methods relating to merger acquisitions in the high-technology sector. The operations studied mainly fulfil sectoral and international diversification objectives. We have found that almost all the initiating companies are grouped together in 8 sectors, with the great majority operating in the United States. For two thirds of the cases studied, the operating procedure consists in acquiring directly $100 \%$ of the target in one single transaction. For transactions carried out by small structures (acquirers and targets), direct takeover accounts for over $90 \%$ of cases and is close to $96 \%$ if the objective is international diversification. This tends to shorten the time taken to complete the transaction and leads to greater appreciation of acquisition transactions (except for small transactions). However, where the objective is sectoral diversification, size does not appear to be a discriminating factor. We have also seen high acquisition premiums when the risks linked to technology are combined with internationalisation and small size. In addition, this research again shows the necessity of having a multi-criteria approach in order to obtain better understanding of the complexity of the transactions, particularly when themergers involve large companies and small organisations in the high-technology sector. The research suggests the need for a new analysis chart on the practical forms of these mergers and on the risk relationship.

\section{References}

Aslani, A. A., \& Negassi, S. (2006). Is technology integration the solution to biotechnology's low research and development productivity? Technovation

Capron, L., \& Mitchell, W. (1998). Bilateral Resource Redeployment and Capabilities Improvement Following Horizontal Acquisitions. Industrial and Corporate Change, 7(3), 453-484. http://dx.doi.org/10.1093/icc/7.3.453

Cassiman, B., \& Veugelers, R. (2002). Complementarity in the Innovation Strategy: Internal R\&D, External Technology Acquisition, and Cooperation in $R \& D$. 
Chesbrough, H. W. (2003). Open Innovation: The New Imparative for Creating and Profiting from Technology. Boston. Harvard Business School Press.

Cloodt, M., Hagedoorn, J., \& Van Kranenburg, H. (2006). Mergers and acquisitions: Theireffect on the innovative performance of companies in high-tech industries. Research Policy, 35(5), 642-654. http://dx.doi.org/10.1016/j.respol.2006.02.007

Coff, R. W. (1999). How buyers cope with uncertainty when acquiring firms in knowledge-intensive industries: Caveat emptor. Organization Science, 10, 144-161. http://dx.doi.org/10.1287/orsc.10.2.144

Cohen, W., \& Levinthal, D. (1990). Absorptive capacity: A new perspective on learning an innovation. Administrative Science Quarterly, 35, 128-152. http://dx.doi.org/10.2307/2393553

Colombo, G., Dell'era, C., \& Frattini, F. (2011). New product development (NPD) servicesuppliers in open innovation practices: Progresses and organization for knowledgeexchange and integration. International Journal of Innovation Management, 15(1), 165-204. http://dx.doi.org/10.1142/S136391961100312X

de Man, A-P., \& Duysters, G. (2005). Collaboration and innovation: A review of the effectsof mergers, acquisitions and alliances on innovation. Technovation, 25(3), 1377-1387. http://dx.doi.org/10.1016/j.technovation.2004.07.021

Granstrand, O., \& Sjölander, S. (1990). The Acquisition of Technologi and Small Firms by Large Firms. Journal of Economic Behavior and Organization, 13, 367-386. http://dx.doi.org/10.1016/0167-2681(90)90006-Y

Grimpe, C. (2007). Successful product development after firm acquisitions: The role of research and development. Journal of Product Innovation Management, 24(6), 614-628. http://dx.doi.org/10.1111/j.1540-5885.2007.00275.x

Gugler, K., Mueller, D. C., \& Yuroglu, B. B. (2003). The Determinants of Merger Waves. Mimeo, University of Vienna.

Holms, T. J., \& Schmitz, J. A. (1990). A theory of entrepreneurship and its application to the study of business transfers. The Journal of Political Economy. http://dx.doi.org/10.1086/261678

Inkpen, A. C., Sundaram, A. K., \& Rockwood, K. (2000). Cross-Border Acquisitions of US Technology Assets. California Management Review, 42(3), 50-71.

Katz, M. L., \& Shapiro, C. (1986). How to License Intangible Property. Quaterly Journal of Economics, 101, 567-590. http://dx.doi.org/10.2307/1885697

Lee, K. S., Lim, G. H., Tan, S. J., \& Wee, C. H. (2001). Generic marketing strategies for small and medium-sized enterprises - conceptual framework and examples from Asia. Journal of Strategic Marketing, 9, 145-162. http://dx.doi.org/10.1080/09652540122176

Lichtenberg, F. R. (1992). Industrial Diversification and its Consequences for Productivity. Journal of Economic Behaviour Organization, 18, 427-438. http://dx.doi.org/10.1016/0167-2681(92)90019-8

Luypaert, M., \& Huyghebaert, N. (2007). Determinants of growth through mergers and acquisitions: An empirical analysis. In 25th Erasmus finance day, Rotterdam (The Netherlands). Working paper.

Makri, M., Hitt, M. A., \& Lane, P. J. (2010). Complementary technologies, knowledge relatedness,and invention outcomes in high technology mergers and acquisitions. Strategic Management Journal, 31(6), 602-628.

Meier, O., Missionier, A., \& Soparnot, R. (2011). The evolution of the governance model ininstances of highly innovative strategic mergers. Corporate Governance, 11(3), 256-273. http://dx.doi.org/10.1108/14720701111138689

Meier, O., \& Schier, G. (2012). Fusions-Acquisitions: Stratégie, Finance, Management. Dunod $4{ }^{\text {ème }}$ édition.

Moeller, S. B., Schlingemann, F. P., \& Stulz, R. M. (2004). Firm Size and the Gains From Acquisitions. Journal of Financial Economics, 73, 201-228. http://dx.doi.org/10.1016/j.jfineco.2003.07.002

Montgomery, C. A. (1994). Corporate Diversification. Journal of Economic Perspectives, 8(3), 163-178. http://dx.doi.org/10.1257/jep.8.3.163

OCDE. (2000). L'observateur, Science, Technologie et innovation dans la nouvelle économie. (www.oecd.org/publications/Pol_breif/) (octobre 2000).

Paruchuri, S., Nerkar, A., \& Hambrick, D. C. (2006). Acquisition integration and productivity losses in the technical core: Disruption of inventors in acquired companies. Organization Science, 17(5), 545-562. http://dx.doi.org/10.1287/orsc.1060.0207 
Puranam, P., Singh, H., \& Chaudhuri, S. R. (2009). Integrating acquired capabilities: When structuralintegration is (un)necessary. Organization Science, 20(2), 313-328. http://dx.doi.org/10.1287/orsc.1090.0422

Rhodes-Kropf, M., \& Viswanathan, S. (2004). Market Valuation and Merger Waves. Journal of Finance, 59, 2685-2718. http://dx.doi.org/10.1111/j.1540-6261.2004.00713.x

Salant, S. W. (1984). Preemptive Patenting and the Persistence of Monopoly: Comment. American Economic Review, 74, 247-253.

Schier, G., \& Navatte, P. (2010). La vague de fusions - acquisitions des années 1990 aux Etats-Unis: Une lecture des résultats à l'aide de la théorie de l'agence. Revue Française de Gestion, 204, 53-67.

Spithoven, A., \& Teirlinck, P. (2010). External R\&D: Exploring the functions and qualifications of R\&D personnel. International Journal of Innovation Management, 14(6), 967-987. http://dx.doi.org/10.1142/S1363919610002969

Vermeulen, F., \& Barkema, H. (2001). Learning Through Acquisitions. Academy of Management Journal, 44(3), 457-476. http://dx.doi.org/10.2307/3069364

Williamson, O. E. (1975). Market and Hierarchies: Analysis and Antitrust Implications. New-York: Free Press.

Table 1. Medium sized international high tech acquisitions

\begin{tabular}{|c|c|c|c|c|c|c|c|}
\hline & \multicolumn{3}{|c|}{ High-Tech Acquisitions (full sample) } & \multicolumn{4}{|c|}{ H/Tech Acquisitions (international diversification) } \\
\hline & $\begin{array}{c}\text { Number of } \\
\text { High Tech } \\
\text { acquisitions }\end{array}$ & $\begin{array}{c}\text { Total } \\
\text { Transaction } \\
\text { Value } \\
\text { (millions \$) }\end{array}$ & $\begin{array}{c}\text { Average } \\
\text { Transaction } \\
\text { Value } \\
\text { (millions \$) }\end{array}$ & $\begin{array}{l}\text { Number of } \\
\text { High Tech } \\
\text { acquisitions }\end{array}$ & $\begin{array}{c}\% \text { of total } \\
\text { High-Tech } \\
\text { Acquisitions }\end{array}$ & $\begin{array}{c}\text { Total } \\
\text { Transaction } \\
\text { Value } \\
\text { (millions \$) }\end{array}$ & $\begin{array}{c}\text { Average } \\
\text { Transaction } \\
\text { Value } \\
\text { (millions \$) }\end{array}$ \\
\hline 1990 & 22 & 1654.3 & 75.20 & 3 & $13.6 \%$ & 221.59 & 73.9 \\
\hline 1991 & 42 & 3920.3 & 93.34 & 9 & $21.4 \%$ & 422.14 & 46.9 \\
\hline 1992 & 44 & 3009.5 & 68.40 & 6 & $13.6 \%$ & 210.15 & 35.0 \\
\hline 1993 & 65 & 3479.1 & 53.52 & 13 & $20.0 \%$ & 720.43 & 55.4 \\
\hline 1994 & 99 & 9229.7 & 93.23 & 19 & $19.2 \%$ & 1172.61 & 61.7 \\
\hline 1995 & 129 & 11786.6 & 91.37 & 27 & $20.9 \%$ & 2256.71 & 83.6 \\
\hline 1996 & 177 & 15458.8 & 87.34 & 47 & $26.6 \%$ & 3879.03 & 82.5 \\
\hline 1997 & 213 & 21220.0 & 99.62 & 55 & $25.8 \%$ & 5164.19 & 93.9 \\
\hline 1998 & 325 & 26982.2 & 83.02 & 95 & $29.2 \%$ & 7171.20 & 75.5 \\
\hline 1999 & 439 & 44119.5 & 100.50 & 114 & $26.0 \%$ & 8819.29 & 77.4 \\
\hline 2000 & 602 & 62596.1 & 103.98 & 185 & $30.7 \%$ & 17038.55 & 92.1 \\
\hline 2001 & 355 & 30624.1 & 86.26 & 104 & $29.3 \%$ & 9969.69 & 95.9 \\
\hline 2002 & 266 & 21221.0 & 79.78 & 76 & $28.6 \%$ & 6120.17 & 80.5 \\
\hline 2003 & 305 & 24547.1 & 80.48 & 78 & $25.6 \%$ & 6232.10 & 79.9 \\
\hline 2004 & 343 & 30121.5 & 87.82 & 115 & $33.5 \%$ & 9891.74 & 86.0 \\
\hline 2005 & 394 & 33646.8 & 85.40 & 136 & $34.5 \%$ & 11383.66 & 83.7 \\
\hline 2006 & 384 & 33100.2 & 86.20 & 140 & $36.5 \%$ & 12357.97 & 88.3 \\
\hline 2007 & 411 & 36811.9 & 89.57 & 133 & $32.4 \%$ & 11987.07 & 90.1 \\
\hline 2008 & 350 & 27943.2 & 79.84 & 124 & $35.4 \%$ & 9953.82 & 80.3 \\
\hline 2009 & 238 & 22413.9 & 94.18 & 78 & $32.8 \%$ & 7927.48 & 101.6 \\
\hline 2010 & 278 & 26969.8 & 97.01 & 99 & $35.6 \%$ & 8862.89 & 89.5 \\
\hline 2011 & 257 & 23019.2 & 89.57 & 82 & $31.9 \%$ & 8307.42 & 101.3 \\
\hline & 5738 & & 86.62 & 1738 & $30.3 \%$ & & 79.77 \\
\hline
\end{tabular}

\begin{tabular}{cccc}
\hline H/Tech Acquisitions (Sectoral Diversification) & \\
\hline $\begin{array}{c}\text { Number of } \\
\text { High Tech } \\
\text { acquisitions }\end{array}$ & $\begin{array}{c}\text { \% of total } \\
\text { High-Tech } \\
\text { Acquisitions }\end{array}$ & $\begin{array}{c}\text { Total } \\
\text { Transaction } \\
\text { Value } \\
\text { (millions \$) }\end{array}$ & $\begin{array}{c}\text { Average } \\
\text { Transaction } \\
\text { Value } \\
\text { (millions \$) }\end{array}$ \\
\hline 16 & $72.7 \%$ & 1372.0 & 85.8 \\
35 & $83.3 \%$ & 3273.8 & 93.5 \\
32 & $72.7 \%$ & 1794.6 & 56.1 \\
56 & $86.2 \%$ & 3025.0 & 54.0 \\
78 & $78.8 \%$ & 8158.7 & 104.6 \\
91 & $70.5 \%$ & 8170.5 & 89.8 \\
142 & $80.2 \%$ & 11975.8 & 84.3 \\
163 & $76.5 \%$ & 15725.4 & 96.5 \\
252 & $77.5 \%$ & 20672.4 & 82.0 \\
340 & $77.4 \%$ & 34587.2 & 101.7 \\
463 & $76.9 \%$ & 49046.9 & 105.9 \\
267 & $75.2 \%$ & 23237.5 & 87.0 \\
200 & $75.2 \%$ & 15841.4 & 79.2 \\
221 & $72.5 \%$ & 18557.9 & 84.0 \\
245 & $71.4 \%$ & 21799.7 & 89.0 \\
283 & $71.8 \%$ & 24306.6 & 85.9 \\
272 & $70.8 \%$ & 24226.5 & 89.1 \\
271 & $65.9 \%$ & 23030.0 & 85.0 \\
248 & $70.9 \%$ & 20206.3 & 81.5 \\
160 & $67.2 \%$ & 14970.8 & 93.6 \\
183 & $65.8 \%$ & 18197.7 & 99.4 \\
180 & $70.0 \%$ & 15878.6 & 88.2 \\
& & & \\
\hline 4198 & $73.2 \%$ & & 87.10 \\
\hline & & & \\
\hline
\end{tabular}


Table 2. Acquirer nations of medium sized high-tech acquisitions (1990-2011)

\begin{tabular}{|c|c|c|c|c|c|c|c|}
\hline $\begin{array}{l}\text { Acquiror } \\
\text { Nation }\end{array}$ & $\begin{array}{l}\text { Number of High- } \\
\text { Tech Acquisitions }\end{array}$ & $\begin{array}{c}\text { Total Trans action } \\
\text { Value (in millons } \\
\text { \$) }\end{array}$ & $\begin{array}{l}\text { Average Transaction } \\
\text { Value (in millons \$) }\end{array}$ & $\begin{array}{l}\text { Acquiror } \\
\text { Nation }\end{array}$ & $\begin{array}{c}\text { Number of } \\
\text { High-Tech } \\
\text { Acquisitions }\end{array}$ & $\begin{array}{c}\text { Total } \\
\text { Transaction } \\
\text { Value (in }\end{array}$ & $\begin{array}{c}\text { Average } \\
\text { Transaction } \\
\text { Value (in }\end{array}$ \\
\hline United States & 3112 & 319483.3 & 102.7 & Guernsey & 8 & 1257.7 & 157.2 \\
\hline Japan & 428 & 27653.5 & 64.6 & Portugal & 8 & 783.6 & 97.9 \\
\hline United Kingdom & 361 & 26079.1 & 72.2 & Austria & 7 & 642.7 & 91.8 \\
\hline Canada & 176 & 15452.8 & 87.8 & Turkey & 7 & 488.1 & 69.7 \\
\hline South Korea & 142 & 5572.9 & 39.2 & Hungary & 6 & 740.2 & 123.4 \\
\hline Germany & 134 & 9982.5 & 74.5 & Chile & 5 & 267.5 & 53.5 \\
\hline France & 116 & 10380.4 & 89.5 & Egypt & 4 & 132.2 & 33.1 \\
\hline Sweden & 94 & 7754.4 & 82.5 & New Zealand & 4 & 140.7 & 35.2 \\
\hline China & 91 & 4252.8 & 46.7 & Saudi Arabia & 4 & 504.3 & 126.1 \\
\hline India & 87 & 5605.4 & 64.4 & Slovenia & 4 & 337.1 & 84.3 \\
\hline Australia & 80 & 5648.7 & 70.6 & Thailand & 4 & 299.6 & 74.9 \\
\hline Hong Kong & 64 & 3642.7 & 56.9 & Iceland & 3 & 207.0 & 69.0 \\
\hline Taiwan & 64 & 5083.2 & 79.4 & Malta & 3 & 135.5 & 45.2 \\
\hline Italy & 59 & 3452.2 & 58.5 & Czech Republic & 2 & 64.2 & 32.1 \\
\hline Brazil & 58 & 4644.6 & 80.1 & Luxembourg & 2 & 251.2 & 125.6 \\
\hline Russian Fed & 56 & 5238.4 & 93.5 & Philippines & 2 & 401.9 & 200.9 \\
\hline Netherlands & 54 & 5547.0 & 102.7 & Utd Arab Em & 2 & 91.0 & 45.5 \\
\hline Norway & 54 & 3089.1 & 57.2 & Argentina & 1 & 23.7 & 23.7 \\
\hline Singapore & 51 & 4018.5 & 78.8 & Bahrain & 1 & 415.0 & 415.0 \\
\hline Israel & 48 & 4618.1 & 96.2 & Bulgaria & 1 & 15.5 & 15.5 \\
\hline Switzerland & 46 & 5785.6 & 125.8 & Croatia & 1 & 42.3 & 42.3 \\
\hline Finland & 45 & 4131.5 & 91.8 & Cyprus & 1 & 15.7 & 15.7 \\
\hline South Africa & 34 & 3438.2 & 101.1 & Estonia & 1 & 74.1 & 74.1 \\
\hline Denmark & 30 & 1732.6 & 57.8 & Gibraltar & 1 & 157.8 & 157.8 \\
\hline Spain & 27 & 1912.6 & 70.8 & Isle of Man & 1 & 50.0 & 50.0 \\
\hline Poland & 23 & 1341.9 & 58.3 & Kuwait & 1 & 34.4 & 34.4 \\
\hline Malaysia & 22 & 1594.4 & 72.5 & Lithuania & 1 & 179.8 & 179.8 \\
\hline Belgium & 19 & 1271.9 & 66.9 & Neth Antilles & 1 & 20.5 & 20.5 \\
\hline Ireland-Rep & 19 & 2139.2 & 112.6 & Oman & 1 & 204.0 & 204.0 \\
\hline Bermuda & 15 & 1924.3 & 128.3 & Peru & 1 & 12.0 & 12.0 \\
\hline Greece & 13 & 936.7 & 72.1 & Qatar & 1 & 28.6 & 28.6 \\
\hline Mexico & 13 & 1143.2 & 87.9 & Slovak Rep & 1 & 11.6 & 11.6 \\
\hline Indonesia & 12 & 1284.0 & 107.0 & Sri Lanka & 1 & 10.0 & 10.0 \\
\hline
\end{tabular}

Table 3. Acquirer industry sectors (full sample) 1990-2011

\begin{tabular}{|c|c|c|c|}
\hline Acquiror Industry Sector & $\begin{array}{l}\text { Number of } \\
\text { High Tech } \\
\text { acquisitions }\end{array}$ & Acquiror Industry Sector & $\begin{array}{l}\text { Number of } \\
\text { High Tech } \\
\text { acquisitions }\end{array}$ \\
\hline Business Services & 1168 & Amusement and Recreation Services & 12 \\
\hline Prepackaged Software & 1016 & Transportation and Shipping (except air) & 11 \\
\hline Telecommunications & 597 & Holding Companies, Except Banks & 9 \\
\hline Electronic and Electrical Equipment & 591 & Rubber and Miscellaneous Plastic Products & 9 \\
\hline Drugs & 577 & Miscellaneous Manufacturing & 8 \\
\hline Measuring, Medical, Photo Equipment; Clocks & 522 & Construction Firms & 8 \\
\hline Computer and Office Equipment & 340 & Retail Trade-Home Furnishings & 7 \\
\hline Communications Equipment & 263 & Educational Services & 6 \\
\hline Radio and Television Broadcasting Stations & 92 & Credit Institutions & 4 \\
\hline Health Services & 77 & Electric, Gas, and Water Distribution & 3 \\
\hline Wholesale Trade-Durable Goods & 56 & Real Estate; Mortgage Bankers and Brokers & 3 \\
\hline Machinery & 50 & Oil and Gas; Petroleum Refining & 3 \\
\hline Metal and Metal Products & 46 & Stone, Clay, Glass, and Concrete Products & 3 \\
\hline Miscellaneous Retail Trade & 42 & Food and Kindred Products & 3 \\
\hline Investment \& Commodity Firms,Dealers,Exchanges & 37 & Soaps, Cosmetics, and Personal-Care Products & 2 \\
\hline Printing, Publishing, and Allied Services & 33 & Agriculture, Forestry, and Fishing & 2 \\
\hline Advertising Services & 26 & Leather and Leather Products & 2 \\
\hline Aerospace and Aircraft & 22 & Textile and Apparel Products & 2 \\
\hline Chemicals and Allied Products & 21 & Wood Products, Furniture, and Fixtures & 2 \\
\hline Motion Picture Production and Distribution & 16 & Other Financial & 1 \\
\hline Transportation Equipment & 16 & Commercial Banks, Bank Holding Companies & 1 \\
\hline Insurance & 15 & Public Administration & 1 \\
\hline Wholesale Trade-Nondurable Goods & 13 & TOTAL & 5738 \\
\hline
\end{tabular}


Table 4. Strategicaloptions according to the size and nature of diversification

\begin{tabular}{|c|c|c|c|c|}
\hline \multicolumn{5}{|c|}{ No diversification } \\
\hline Acquiror= & Group 1 & Group 1 & Group 2 & Group 2 \\
\hline Target= & Group 1 & Group 2 & Group 1 & Group 2 \\
\hline Option 1 & $94.0 \%$ & $74.6 \%$ & $80.7 \%$ & $68.2 \%$ \\
\hline Option 2 & $2.8 \%$ & $4.2 \%$ & $10.7 \%$ & $6.6 \%$ \\
\hline Option 3 & $0.9 \%$ & $7.0 \%$ & $0.9 \%$ & $6.1 \%$ \\
\hline Option 4 & $1.4 \%$ & $8.5 \%$ & $1.5 \%$ & $6.4 \%$ \\
\hline \multirow[t]{2}{*}{ Option 5} & $0.9 \%$ & $5.6 \%$ & $6.1 \%$ & $12.7 \%$ \\
\hline & $100.0 \%$ & $100.0 \%$ & $100.0 \%$ & $100.0 \%$ \\
\hline \multicolumn{5}{|c|}{ Sectoral diversification } \\
\hline Acquiror= & Group 1 & Group 1 & Group 2 & Group 2 \\
\hline Target $=$ & Group 1 & Group 2 & Group 1 & Group 2 \\
\hline Option 1 & $87.7 \%$ & $75.1 \%$ & $84.4 \%$ & $67.0 \%$ \\
\hline Option 2 & $7.3 \%$ & $4.3 \%$ & $6.4 \%$ & $8.2 \%$ \\
\hline Option 3 & $1.6 \%$ & $5.9 \%$ & $2.9 \%$ & $8.2 \%$ \\
\hline Option 4 & $1.8 \%$ & $8.1 \%$ & $1.6 \%$ & $7.9 \%$ \\
\hline \multirow[t]{2}{*}{ Option 5} & $1.6 \%$ & $6.5 \%$ & $4.7 \%$ & $8.6 \%$ \\
\hline & $100.0 \%$ & $100.0 \%$ & $100.0 \%$ & $100.0 \%$ \\
\hline \multicolumn{5}{|l|}{ Full sample } \\
\hline Acquiror $=$ & Group 1 & Group 1 & Group 2 & Group 2 \\
\hline Target $=$ & Group 1 & Group 2 & Group 1 & Group 2 \\
\hline Option 1 & $90.2 \%$ & $74.7 \%$ & $82.8 \%$ & $63.6 \%$ \\
\hline Option 2 & $5.3 \%$ & $4.9 \%$ & $8.3 \%$ & $9.1 \%$ \\
\hline Option 3 & $1.4 \%$ & $6.7 \%$ & $3.0 \%$ & $9.7 \%$ \\
\hline Option 4 & $1.4 \%$ & $7.6 \%$ & $1.4 \%$ & $7.7 \%$ \\
\hline \multirow[t]{2}{*}{ Option 5} & $1.7 \%$ & $6.1 \%$ & $4.5 \%$ & $9.9 \%$ \\
\hline & $100.0 \%$ & $100.0 \%$ & $100.0 \%$ & $100.0 \%$ \\
\hline
\end{tabular}

\begin{tabular}{rcccc}
\multicolumn{2}{l}{ International diversification } & & & \\
\hline Acquiror= & Group 1 & Group 1 & Group 2 & Group 2 \\
Target $=$ & Group 1 & Group 2 & Group 1 & Group 2 \\
Option 1 & $95.7 \%$ & $60.6 \%$ & $74.7 \%$ & $55.1 \%$ \\
Option 2 & $1.4 \%$ & $6.1 \%$ & $14.0 \%$ & $12.3 \%$ \\
Option 3 & $1.4 \%$ & $12.1 \%$ & $4.7 \%$ & $13.1 \%$ \\
Option 4 & $1.4 \%$ & $12.1 \%$ & $2.0 \%$ & $7.2 \%$ \\
Option 5 & $0.0 \%$ & $9.1 \%$ & $4.7 \%$ & $12.3 \%$ \\
& $\mathbf{1 0 0 . 0 \%}$ & $\mathbf{1 0 0 . 0 \%}$ & $\mathbf{1 0 0 . 0} \%$ & $\mathbf{1 0 0 . 0 \%}$ \\
\hline
\end{tabular}

\begin{tabular}{ccccc}
\multicolumn{5}{c}{ Double diversification } \\
\hline $\begin{array}{r}\text { Acquiror= } \\
\text { Target }=\end{array}$ & $\begin{array}{c}\text { Group 1 } \\
\text { Group 1 }\end{array}$ & $\begin{array}{c}\text { Group 1 } \\
\text { Group 2 }\end{array}$ & $\begin{array}{c}\text { Group 2 } \\
\text { Group 1 }\end{array}$ & $\begin{array}{c}\text { Group 2 } \\
\text { Group 2 }\end{array}$ \\
Option 1 & $91.1 \%$ & $81.8 \%$ & $84.0 \%$ & $56.1 \%$ \\
Option 2 & $3.8 \%$ & $7.3 \%$ & $8.5 \%$ & $11.6 \%$ \\
Option 3 & $1.4 \%$ & $5.5 \%$ & $4.3 \%$ & $14.4 \%$ \\
Option 4 & $0.5 \%$ & $1.8 \%$ & $0.5 \%$ & $8.3 \%$ \\
Option 5 & $3.3 \%$ & $3.6 \%$ & $2.7 \%$ & $9.7 \%$ \\
& $\mathbf{1 0 0 . 0 \%}$ & $\mathbf{1 0 0 . 0} \%$ & $\mathbf{1 0 0 . 0 \%}$ & $\mathbf{1 0 0 . 0 \%}$ \\
\hline
\end{tabular}

Table 5a. Diversification types versus acquisitions characteristics (length of acquisition process / average premium paid)

\begin{tabular}{|c|c|c|c|c|c|c|c|c|c|c|c|c|c|c|c|c|c|c|}
\hline & \multicolumn{2}{|c|}{ All groups } & \multicolumn{3}{|c|}{$\begin{array}{c}\text { Acquiror = Group } 1 \\
\text { Target = Group } 1\end{array}$} & & \multicolumn{3}{|c|}{$\begin{array}{c}\text { Acquiror = Group } 1 \\
\text { Target = Group } 2\end{array}$} & \multicolumn{4}{|c|}{$\begin{array}{c}\text { Acquiror = Group } 2 \\
\text { Target = Group } 1\end{array}$} & \multicolumn{4}{|c|}{$\begin{array}{c}\text { Acquiror = Group } 2 \\
\text { Target = Group } 2\end{array}$} & \\
\hline & $N$ & Mean & $N$ & St. Dev & Mean & & $N$ & St. Dev & Mean & & $N$ & St. Dev & Mean & & $N$ & St. Dev & Mean & \\
\hline \multicolumn{18}{|c|}{ A. Length of acquisition process (number of days between annoucement and completion dates) } & \\
\hline Full sample & 5737 & 69.6 & 1060 & 103.1 & 70.5 & & 344 & 135.3 & 84.0 & & 1726 & 113.4 & 53.4 & & 2607 & 104.1 & 78.2 & \\
\hline$(t-t e s t 1)$ & & & & & 0.25 & & & & 1.96 & $(*)$ & & & -5.94 & $(* *)$ & & & 4.18 & $(* *)$ \\
\hline No diversification & 1051 & 73.7 & 215 & 113.2 & 77.2 & & 71 & 89.9 & 84.7 & & 326 & 76.4 & 52.7 & & 439 & 115.4 & 85.8 & \\
\hline$(t-t e s t 1)$ & & & & & 0.46 & & & & 1.03 & & & & -4.97 & $(* *)$ & & & 2.20 & $(*)$ \\
\hline$(t-t e s t 2)$ & & & & & 0.88 & & & & 0.07 & & & & -0.19 & & & & 1.38 & \\
\hline International diversification & 488 & 56.8 & 69 & 63.3 & 45.7 & & 33 & 107.5 & 79.2 & & 150 & 59.3 & 37.3 & & 236 & 94.5 & 69.3 & \\
\hline$(t-t e s t 1)$ & & & & & -1.46 & & & & 1.20 & & & & -4.03 & $(* *)$ & & & 2.03 & $(*)$ \\
\hline$(t-t e s t 2)$ & & & & & -3.25 & $(* *)$ & & & -0.25 & & & & -3.33 & $(* *)$ & & & -1.44 & \\
\hline Sectoral diversficiation & 2948 & 73.1 & 563 & 106.1 & 74.8 & & 185 & 160.8 & 84.1 & & 874 & 115.7 & 58.8 & & 1326 & 101.0 & 80.2 & \\
\hline$(t-t e s t 1)$ & & & & & 0.37 & & & & 0.93 & & & & -3.65 & $(* *)$ & & & 2.58 & $(* *)$ \\
\hline$(t-t e s t 2)$ & & & & & 0.96 & & & & 0.01 & & & & 1.37 & & & & 0.75 & \\
\hline Double diversification & 1250 & 63.2 & 213 & 92.9 & 60.2 & & 55 & 103.9 & 85.4 & & 376 & 146.0 & 48.1 & & 606 & 105.1 & 71.6 & \\
\hline$(t-t e s t 1)$ & & & & & -0.46 & & & & 1.59 & & & & -2.01 & $(*)$ & & & 1.96 & $(*)$ \\
\hline$(t-t e s t 2)$ & & & & & -1.60 & & & & 0.10 & & & & -0.71 & & & & -1.54 & \\
\hline \multicolumn{19}{|c|}{ B. Average Premium Paid (4 weeks prior to announcement date) } \\
\hline Full sample & 4166 & $51.3 \%$ & 889 & $54.5 \%[$ & $58.3 \%$ & & 242 & $37.0 \%$ & $44.7 \%$ & & 1429 & $46.0 \%$ & $55.5 \%$ & & 1606 & $47.1 \%$ & $44.6 \%$ & \rfloor$(* *)$ \\
\hline$(t-t e s t 1)$ & & & & & 3.84 & $(* *)$ & & & -2.77 & $(* *)$ & & & 3.45 & $(* *)$ & & & -5.66 & \\
\hline No diversification & 778 & $48.1 \%$ & 178 & $60.9 \%[$ & $86.1 \%$ & & 47 & $27.9 \%$ & $23.0 \%$ & & 268 & $26.8 \%$ & $39.2 \%$ & & 285 & $30.8 \%$ & $36.9 \%$ & $\beth(* *)$ \\
\hline$(t-t e s t 1)$ & & & & & 8.32 & $(* *)$ & & & -6.17 & $(* *)$ & & & -5.43 & $(* *)$ & & & -6.14 & $(* *)$ \\
\hline$(t-t e s t 2)$ & & & & & 6.08 & $(* *)$ & & & -5.33 & $(* *)$ & & & -9.94 & $(* *)$ & & & -4.24 & \\
\hline International diversification & 399 & $61.6 \%$ & 64 & $34.9 \%[$ & $90.7 \%$ & & 26 & $30.4 \%$ & $51.8 \%$ & & 134 & $34.2 \%$ & $52.7 \%$ & & 175 & $41.5 \%$ & $59.3 \%$ & \\
\hline$(t-t e s t 1)$ & & & & & 6.67 & $(* *)$ & & & -1.65 & & & & -3.04 & $(* *)$ & & & -0.74 & $(* *)$ \\
\hline$(t-t e s t 2)$ & & & & & 7.43 & $(* *)$ & & & 1.19 & & & & -0.96 & & & & 4.67 & \\
\hline Sectoral diversficiation & 2027 & $49.2 \%$ & 459 & $61.8 \%[$ & $48.1 \%$ & & 127 & $41.4 \%$ & $49.2 \%$ & & 699 & $51.6 \%$ & $55.6 \%$ & & 742 & $54.8 \%$ & $43.9 \%$ & ]$(* *)$ \\
\hline$(t$-test 1$)$ & & & & & -0.39 & & & & 0.00 & & & & 3.26 & $(* *)$ & & & -2.63 & \\
\hline$(t-t e s t 2)$ & & & & & -3.55 & $(* *)$ & & & 1.23 & & & & 0.04 & & & & -0.36 & \\
\hline Double diversification & 962 & $59.2 \%$ & 188 & $23.4 \%[$ & $53.4 \%$ & & 42 & $35.1 \%$ & $60.7 \%$ & & 328 & $49.6 \%$ & $75.8 \%$ & & 404 & $39.6 \%$ & $48.3 \%$ & $(* *)$ \\
\hline$(t-t e s t 1)$ & & & & & -3.42 & $(* *)$ & & & 0.28 & & & & 6.07 & $(* *)$ & & & -5.54 & \\
\hline$(t$-test2) & & & & & -2.91 & $(* *)$ & & & 2.95 & $(* *)$ & & & 7.41 & $(* *)$ & & & 1.83 & \\
\hline
\end{tabular}


Table 5 b. Diversification types versus acquisitionvaluation ratios

\begin{tabular}{|c|c|c|c|c|c|c|c|c|c|c|c|c|c|c|c|c|c|c|}
\hline & \multicolumn{2}{|c|}{ All groups } & \multicolumn{3}{|c|}{$\begin{array}{c}\text { Acquiror = Group } 1 \\
\text { Target = Group } 1\end{array}$} & \multicolumn{4}{|c|}{$\begin{array}{c}\text { Acquiror = Group } 1 \\
\text { Target = Group } 2\end{array}$} & \multicolumn{4}{|c|}{$\begin{array}{c}\text { Acquiror = Group } 2 \\
\text { Target = Group } 1\end{array}$} & \multicolumn{5}{|c|}{$\begin{array}{c}\text { Acquiror = Group } 2 \\
\text { Target = Group } 2\end{array}$} \\
\hline & $\mathbf{N}$ & Mean & $\mathbf{N}$ & St. Dev & Mean & & $\mathbf{N}$ & St. Dev & Mean & & $\mathbf{N}$ & St. Dev & Mean & & $\mathbf{N}$ & St. Dev & Mean & \\
\hline \multicolumn{19}{|c|}{ C. Targe Market value of Equity to Sales ratio } \\
\hline Full sample & 5731 & 22.6 & 1060 & 89.7 & 14.5 & & 342 & 141.7 & 35.8 & & 1725 & 101.3 & 10.6 & & 2604 & 316.2 & 32.1 & \\
\hline$(t$-test1) & & & & & -2.94 & $(* *)$ & & & 1.72 & & & & -4.91 & $(* *)$ & & & 1.53 & \\
\hline No diversification & 1049 & 20.2 & 215 & 41.1 & 12.5 & & 71 & 132.6 & 52.9 & & 325 & 48.3 & 10.6 & & 438 & 224.6 & 25.8 & \\
\hline$(t$-test 1$)$ & & & & & -2.75 & $(* *)$ & & & 2.08 & $(*)$ & & & -3.57 & $(* *)$ & & & 0.52 & \\
\hline (t-test2) & & & & & -0.73 & & & & 1.09 & & & & -0.01 & & & & -0.59 & \\
\hline International diversification & 486 & 33.4 & 69 & 246.8 & 54.1 & & 32 & 161.8 & 62.1 & & 150 & 69.8 & 17.0 & & 235 & 183.0 & 34.0 & \\
\hline$(t-t e s t 1)$ & & & & & 0.70 & & & & 1.00 & & & & -2.89 & $(* *)$ & & & 0.05 & \\
\hline$(t-t e s t 2)$ & & & & & 1.33 & & & & 0.92 & & & & 1.11 & & & & 0.16 & \\
\hline Sectoral diversficiation & 2946 & 18.2 & 563 & 52.0 & 9.5 & & 184 & 62.6 & 17.3 & & 874 & 130.0 & 11.6 & & 1325 & 229.7 & 26.3 & \\
\hline$(t$-test1) & & & & & -3.97 & $(* *)$ & & & -0.19 & & & & -1.50 & & & & 1.29 & \\
\hline$(t-t e s t 2)$ & & & & & -2.30 & $(*)$ & & & -4.02 & $(* *)$ & & & 0.21 & & & & -0.92 & \\
\hline Double diversification & 1250 & 34.0 & 213 & 145.0 & 24.4 & & 55 & 330.4 & 79.8 & & 376 & 19.5 & 5.5 & & 606 & 529.2 & 50.8 & \\
\hline$($ t-test1) & & & & & -0.96 & & & & 1.03 & & & & -28.35 & $(* *)$ & & & 0.79 & \\
\hline$(t$-test2) & & & & & 0.99 & & & & 0.99 & & & & -5.13 & $(* *)$ & & & 0.87 & \\
\hline \multicolumn{19}{|c|}{ D. Target market value of Equity to EBIT ratio } \\
\hline Full sample & 5738 & 66.2 & 1060 & 344.3 & 81.1 & & 344 & 106.1 & 54.6 & & 1726 & 324.6 & 70.8 & & 2608 & 273.8 & 58.7 & \\
\hline$(t$-test1) & & & & & 1.40 & & & & -2.02 & $(*)$ & & & 0.59 & & & & -1.41 & \\
\hline No diversification & 1052 & 65.4 & 215 & 47.8[ & 33.7 & & 71 & 31.3[ & 34.2 & & 326 & 526.5 & 125.2 & & 440 & 69.5[ & 41.6 & \\
\hline$(t-$ test1) & & & & & -9.71 & $(* *)$ & & & -8.42 & $(* *)$ & & & 2.05 & $(*)$ & & & -7.18 & $(* *)$ \\
\hline$(t-t e s t 2)$ & & & & & -14.52 & $(* *)$ & & & -5.52 & $(* *)$ & & & 1.87 & & & & -5.16 & $(* *)$ \\
\hline International diversification & 488 & 142.7 & 69 & 15.1 & 25.4 & & 33 & 47.5 & 51.4 & & 150 & 511.5 & 172.4 & & 236 & 773.4 & 170.9 & \\
\hline$(t$-test 1$)$ & & & & & -64.74 & $(* *)$ & & & -11.05 & $(* *)$ & & & 0.71 & & & & 0.56 & \\
\hline$(t-t e s t 2)$ & & & & & -30.72 & $(* *)$ & & & -0.39 & & & & 2.43 & $\left(^{*}\right)$ & & & 2.23 & $(*)$ \\
\hline Sectoral diversficiation & 2948 & 57.0 & 563 & 420.5 & 99.2 & & 185 & 54.8 & 48.9 & & 874 & 269.7 & 54.9 & & 1326 & 71.1 & 41.7 & \\
\hline$(t$-test1) & & & & & 2.38 & $(*)$ & & & -2.02 & $(*)$ & & & -0.24 & & & & -7.86 & $(* *)$ \\
\hline$(t-t e s t 2)$ & & & & & 1.02 & & & & -1.42 & & & & -1.75 & & & & -8.70 & $(* *)$ \\
\hline Double diversification & 1250 & 72.8 & 213 & 273.0 & 94.6 & & 55 & 269.3 & 123.2 & & 376 & 64.8 & 38.4 & & 606 & 385.6 & 81.9 & \\
\hline$(t-t e s t 1)$ & & & & & 1.16 & & & & 1.39 & & & & -10.30 & $(* *)$ & & & 0.58 & \\
\hline$(t-t e s t 2)$ & & & & & 0.72 & & & & 1.89 & & & & -9.70 & $(* *)$ & & & 1.49 & \\
\hline
\end{tabular}

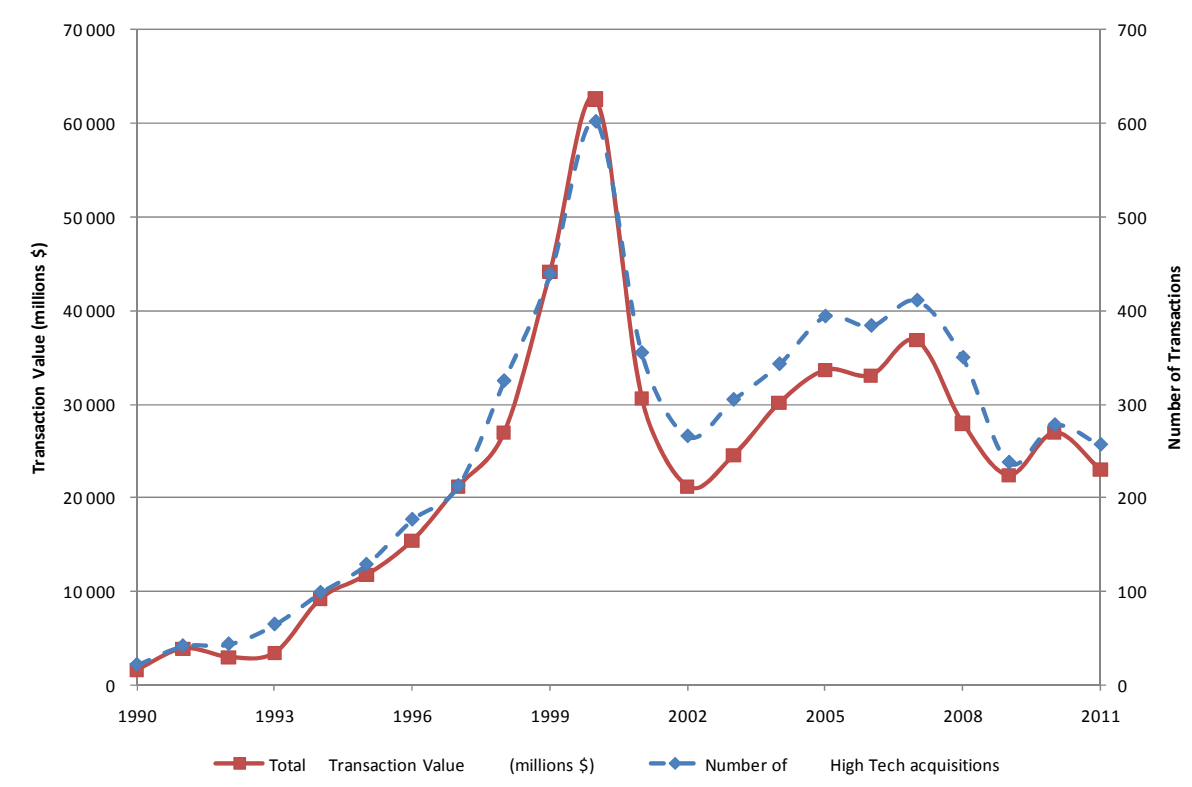

Figure 1. Medium-sized High tech acquisitions waves 


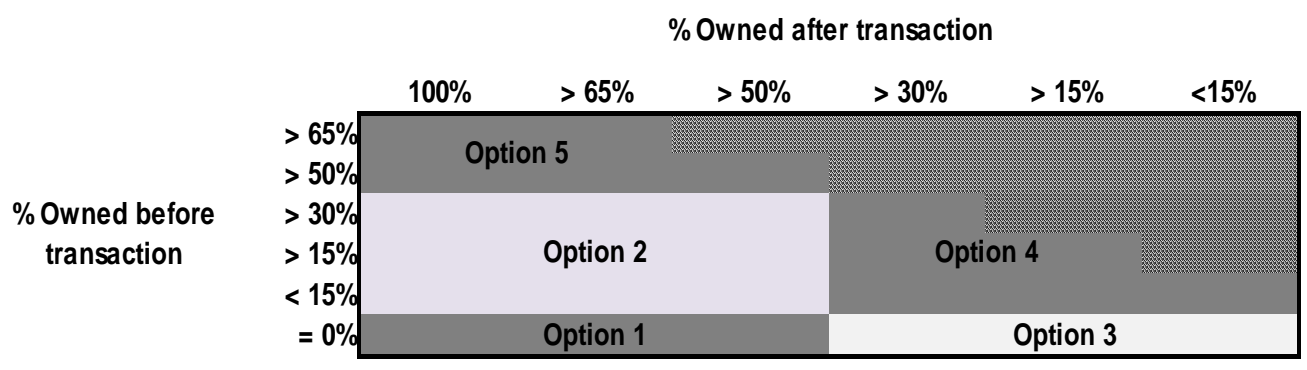

Figure 2. The 5 strategical options in high tech acquisition

\begin{tabular}{cccccccc}
\multicolumn{7}{c}{} & \multicolumn{7}{c}{$\%$ Owned after transaction } \\
& $>65 \%$ & $100 \%$ & $>65 \%$ & $>50 \%$ & $>30 \%$ & $>15 \%$ & $<15 \%$ \\
\% Owned & $>50 \%$ & $2,1 \%$ & $0,7 \%$ & & & & \\
before & $>30 \%$ & $1,0 \%$ & $1,0 \%$ & $0,1 \%$ & & & \\
transaction & $>15 \%$ & $1,0 \%$ & $0,6 \%$ & $0,3 \%$ & $0,1 \%$ & & \\
& $>15 \%$ & $1,4 \%$ & $1,9 \%$ & $0,9 \%$ & $1,1 \%$ & $1,6 \%$ & $1,4 \%$ \\
& $=0 \%$ & $67,0 \%$ & $4,9 \%$ & $3,0 \%$ & $2,2 \%$ & $1,9 \%$ & $1,9 \%$ \\
\hline
\end{tabular}

Figure 3. The 5 strategical options: medium-sized high-tech acquisition cases (1990-2011)

\begin{tabular}{|c|c|c|c|c|c|c|c|c|c|c|}
\hline & & & & $\begin{array}{l}\text { quiror } \\
\text { de of eq }\end{array}$ & $\begin{array}{l}\text { distributio } \\
\text { in million }\end{array}$ & & & & & \\
\hline & & & & & & up 2 & & & & \\
\hline & & & $<26,72$ & $<63,9$ & $<162,25$ & over 162,25 & & & & \\
\hline Target size & & Q1 & 363 & 260 & 327 & 397 & 1347 & & & \\
\hline distribution & Group 1 & Q2 & 205 & 232 & 320 & 682 & 1439 & & & \\
\hline (value of equity & & Q3 & 96 & 148 & 239 & 953 & 1436 & Target qua & size dis & ution \\
\hline in millions \$) & Group 2 & Q4 & 45 & 55 & 195 & 1221 & 1516 & (value of $e$ & $y$ in mill & \\
\hline & & & 709 & 695 & 1081 & 3253 & & & Min & $\operatorname{Max}$ \\
\hline & & & & & & & & Q1 - 25\% & 10 & 26.72 \\
\hline & & & & quiror s & distributiol & & & Q2 - 50\% & 26.72 & 63.9 \\
\hline & & & & & & up 2 & & Q3 - 75\% & 63.9 & 162.25 \\
\hline & & & $<26,72$ & $<63,9$ & $<162,25$ & over 162,25 & & Q4 - 100\% & 162.25 & 500 \\
\hline $\begin{array}{l}\text { Target size } \\
\text { distribution }\end{array}$ & Group 1 & $\begin{array}{l}\text { Q1 } \\
\text { Q2 }\end{array}$ & & & & 26 & & & & \\
\hline $\begin{array}{l}\text { (value of equity } \\
\text { in millions \$) }\end{array}$ & Group 2 & $\begin{array}{l}\text { Q3 } \\
\text { Q4 }\end{array}$ & & & & 308 & & & & \\
\hline
\end{tabular}

Figure 4. Distribution of transactions per size and per size "group" 